\title{
Fiber Characteristics of White Poplar (Populus alba L.) Juvenile Wood along the Drava River
}

\section{Svojstva vlakanaca juvenilnog drva bijele topole (Populus alba L.) uz rijeku Dravu}

\author{
Original scientific paper • Izvorni znanstveni rad \\ Received-prispjelo: 25. 4. 2017. \\ Accepted-prihvaćeno: 30. 8. 2017. \\ UDK: $630 * 811.155 ; 674.031 .623 .234 .1$ \\ doi:10.5552/drind.2017.1729
}

\begin{abstract}
Anatomical properties of white poplar (Populus alba L.) wood have not been sufficiently investigated and quantified, whereas data on fiber characteristics will certainly define its potential as a raw material. Fiber length, double cell wall thickness and fiber lumen diameter of white poplar juvenile wood from two sites along the Drava River in Croatia were measured. Variations in fiber characteristics in radial direction (from pith to bark), within and between white poplar populations from two sites were investigated. Results indicate that fiber Rlength and double cell wall thickness varied significantly from pith to bark, within and between sites. Variation in fiber lumen diameter was non-significant only between sites. The variation in radial pattern was characterized by increase in fiber length with cambial age. Double cell wall thickness and fiber lumen diameter varied in non-consistent radial pattern. In conclusion, variation significance demonstrates nonhomogeneous wood fiber characteristics at both sites.
\end{abstract}

Keywords: Populus alba L., juvenile wood, fiber characteristics, wood anatomical properties variation

SAŽETAK • Anatomska svojstva drva bijele topole (Populus alba L.) nedovoljno su istražena i nisu kvantificirana, a podatci o obilježjima drvnih vlakanaca zasigurno će upozoriti na potencijal tog drva kao sirovine. U radu je izmjerena duljina vlakanaca, dvostruka debljina stijenki i promjer lumena vlakanaca juvenilnog drva bijele topole s dva staništa uz rijeku Dravu. Istražene su i varijacije svojstava vlakanaca u smjeru od srčike prema kori, kao i unutar istog staništa odnosno između dvaju promatranih staništa. Rezultati pokazuju značajne varijacije duljine vlakanaca i dvostruke debljine stijenki od srčike prema kori te unutar istog staništa i između dvaju staništa. Varijacije promjera lumena vlakanaca nisu značajne samo među staništima. Radijalne su varijacije određene rastom duljine vlakanaca sa starošću drva. Dvostruka debljina stijenki i promjer lumena vlakanaca mijenjaju se prema promjenjivom modelu između godova. Zaključno, značenje varijacija upućuje na nehomogenost svojstava drvnih vlakanaca na oba staništa.

Ključne riječi: Populus alba L., juvenilno drvo, svojstva vlakanaca, varijacije anatomskih svojstava drva

\footnotetext{
${ }^{1}$ Authors are postdoctoral researcher, assistant professor, assistant professor, senior technical assistant and postdoctoral researcher at University of Zagreb, Faculty of Forestry, Wood Technology Department, Zagreb, Croatia.

${ }^{1}$ Autori su poslijedoktorandica, docent, docent, viša tehnička suradnica i poslijedoktorand Sveučilišta u Zagrebu, Šumarski fakultet, Drvnotehnološki odsjek, Zagreb, Hrvatska.
} 


\section{INTRODUCTION}

\section{UVOD}

Poplar wood is widely used for the manufacture of a large number and variety of products, especially for pulp, paper and other fiber-based products. It is reported that approximately 70 countries worldwide grow poplars, both in mixtures with other natural forest species and in planted forests (Ball et al., 2005). However, the great majority of poplars still grow in natural forests. The value of diverse natural stands of poplars as a basis for tree improvement is well recognized (Ball et al., 2005). Acquiring genotypes of forest trees or trying to upgrade the existing properties is one of the main aims of tree improvement (Kajba and Ballian, 2007). It is often carried out in order to increase the productivity of the wood mass. The increase of wood quality is another important goal, which cannot be carried out without an understanding of wood structure.

Cell size and relative cell dimensions have a major influence on the quality of pulp and paper based products, as well as on solid wood products (Clark, 1985). Mechanical properties of wood stiffness and strength are, among others, also related to wood fiber characteristics (Logan, 2006).

As they grow so rapidly, both natural and planted poplar stands can produce large volumes of wood in a short period of time (Dickmann and Kuzovkina, 2014). This suggests that they can be harvested within 10-20 years, having a high portion of juvenile wood. Juvenile wood is characterized by rapid changes in wood structure throughout the zone from the pith outward (Tsoumis, 1991). Maeglin (1987) reported shorter fibers with generally thinner walls at or near the pith. According to Dadswell (1958), fiber length is increased up to two times in the central core of hardwoods.

As one of the most distinctive poplar species, white poplar (Populus alba L.) is an indigenous wood species in Europe. In Croatia, white poplar can rarely be found in pure stands covering large areas, but forms mixed stands together with other species, such as white willow and black poplar. However, pure stands of white poplar are found along the Danube, Sava and Drava (Franjić and Škvorc, 2010). For a long period of time, white poplar has not been considered as a commercially important wood species. Due to climate changes and changed ecological conditions, it is becoming more interesting for breeding as a drought tolerant species (Eggens et al., 1972; Gilman and Watson, 1994; Isebrands and Richardson, 2014).

Within the Populus genus, white poplars have been least investigated. Horvat (1960) investigated some physical and mechanical properties of white poplar wood in Croatia. However, available data on anatomical properties of white poplar wood are limited (FAO 1958). The capacity of white poplar to grow in a wide range of soils and to propagate easily contributes highly to its cultivation. For that reason, the available data on its wood anatomical properties should be completed. Additionally, variability in juvenile wood characteristics significantly affects product quality. There- fore, more emphasis should be put on determining the size of wood variability.

The aim of this study was: (a) to determine fiber characteristics of white poplar juvenile wood from two sites along the Drava River in Croatia; (b) to investigate variations in fiber characteristics in radial direction (from pith to bark), within and between white poplar populations from two sites.

\section{MATERIAL AND METHODS}

\section{MATERIJAL I METODE}

Five trees of white poplar (Populus alba L.) were collected from two sites with continental climate along the Drava River. The first site is located near the city of Osijek, within Osijek Podravina forests. It is characterized by alluvial loamy-sandy soils, where humus is being formed, with mean annual temperature of $11.6^{\circ} \mathrm{C}$ and total annual precipitation of $694.4 \mathrm{~mm}$.

The second site is located near the city of Varaždin, within Varaždin Podravina forests. It is characterized by soil on alluvial pebbly-sandy shoals intersected with meanders, with mean annual temperature of $10.8^{\circ} \mathrm{C}$ and total annual precipitation of $819.9 \mathrm{~mm}$. Both units are managed by the company Croatian Forests Ltd.

Each test tree was marked on the side facing north because of further investigations on physical and mechanical properties. Relevant parameters on growth locations of all test trees were collected and measured (Table 1).

Disks, approximately $5 \mathrm{~cm}$ thick, were cut at breast height $(1.3 \mathrm{~m})$ from each tree. Radial segments (north-south orientation) were cut from each disk and annual growth rings were marked along one radius. On both sites, growth rings 2, 4, 6, 8 and 10 from the pith were selected from each tree for further anatomical analysis of wood. A series of radially oriented sample blocks, sized $10(\mathrm{~T}) \times 10(\mathrm{R}) \times 20(\mathrm{~L}) \mathrm{mm}$, was cut from the selected growth rings.

For measuring double cell wall thickness and fiber lumen diameter, transverse sections (30 $\mu \mathrm{m})$ were cut using Shandon Reichert sliding microtome. Sections were then stained with safranin and astra blue, while excess stain was removed by washing sections successively in $70 \%$ and $96 \%$ ethanol solution. Furthermore, they were mounted on microscope slides with coverslips using euparal. Photographs of samples were then taken at $\times 160$ magnification using stereo microscope, digital camera and Axio Vision program (Carl Zeiss). In each growth ring, five images were taken as random replicates: one from the early wood region, one from late wood region and three from the middle part of the growth ring, according to Peszlen (1994). Fiber lumen diameter was measured by digital photographs, using ImageJ program (ImageJ 2014).

Double cell wall thickness was measured directly on light microscope, using an objective with measurement scale. The magnification $\times 960$ was used. From each growth ring, 30 tangential fiber double cell wall thicknesses were measured (ten in the early wood region, ten in the middle part of each growth ring and ten in the late wood region). 
Table 1 Tree characteristics of white poplar (Populus alba L.) from two sites along the Drava River

Tablica 1. Karakteristike stabala bijele topole (Populus alba L.) s dvaju staništa uz rijeku Dravu

\begin{tabular}{|l|c|c|c|c|c|c|c|}
\hline $\begin{array}{l}\text { Tree species } \\
\text { Vrsta drva }\end{array}$ & $\begin{array}{c}\text { Tree } \\
\text { mark } \\
\text { Oznaka } \\
\text { stabla }\end{array}$ & $\begin{array}{c}\text { Site } \\
\text { Stanište }\end{array}$ & $\begin{array}{c}\text { Total tree } \\
\text { height } \\
\text { Ukupna } \\
\text { visina stabla } \\
\mathrm{m}\end{array}$ & $\begin{array}{c}\text { Height up to first } \\
\text { living branch } \\
\text { Visina do prve } \\
\text { žive grane } \\
\mathrm{m}\end{array}$ & $\begin{array}{c}\text { Diameter at } \\
\text { breast height } \\
\text { Promjer na } \\
\text { prsnoj visini } \\
\text { cm }\end{array}$ & $\begin{array}{c}\text { Diameter at breast } \\
\text { height in first 10 years } \\
\text { Promjer na prsnoj visini } \\
\text { u prvih 10 godina } \\
\text { cm }\end{array}$ & $\begin{array}{c}\text { Disk } \\
\text { thickness } \\
\text { Debljina } \\
\text { koluta } \\
\text { cm }\end{array}$ \\
\hline P. alba & 6 & Osijek & 18.1 & 11 & 29.5 & 5.85 & 5 \\
\hline P. alba & 7 & Osijek & 20 & 14 & 35 & 5.42 & 5 \\
\hline P. alba & 8 & Osijek & 18.3 & 11 & 40.5 & 6.55 & 5 \\
\hline P. alba & 9 & Osijek & 18.2 & 10 & 33 & 4.42 & 5 \\
\hline P. alba & 10 & Osijek & 18.7 & 14 & 25.5 & 3.61 & 5 \\
\hline P. alba & 27 & Varaždin & 16 & 7.5 & 50.5 & 4.98 & 5 \\
\hline P. alba & 28 & Varaždin & 14 & 6 & 51 & 7.78 & 5 \\
\hline P. alba & 29 & Varaždin & 14.3 & 8 & 41 & 4.47 & 5 \\
\hline P. alba & 30 & Varaždin & 14.1 & 8.2 & 44.5 & 4.77 & 5 \\
\hline P. alba & 31 & Varaždin & 13 & 7,3 & 39.2 & 2.71 & 5 \\
\hline
\end{tabular}

For fiber length measurements, wood from each of the previously selected growth rings was separated with a razor blade and placed into an individual test tube. Maceration was performed according to Franklin’s method (Franklin, 1945). Macerated material was stained using safranin, then placed on microscope slides and mounted in glycerin gelatin. From each growth ring, 40 unbroken fibers were measured using light microscope, digital camera and DinoCapture 2.0 program (DinoCapture 2.0 2015).

Statistical analysis of results was carried out using Statistica 10. Repeated measures analysis of variance (ANOVA) was used to test significance of differences in radial distribution of selected fiber characteristics, as well as their variations within and between two white poplar populations.

\section{RESULTS AND DISCUSSION}

3. REZULTATI I RASPRAVA

Statistical values of fiber dimensions of white poplar juvenile wood from both sites are given in Table 2.
The mean fiber length of white poplar juvenile wood from Osijek site was $0.87 \mathrm{~mm}$ and from Varaždin site $0.84 \mathrm{~mm}$ (Table 2). Similar mean values of fiber length were determined by Boessneck, Brossa, Viviani and Demi in white poplar wood from several locations in Europe, and they are all less than $1 \mathrm{~mm}$ (in FAO 1958). However, Demi also reported fibers longer than $1 \mathrm{~mm}$. The mean double cell wall thickness of white poplar juvenile wood from Osijek site was $3.72 \mu \mathrm{m}$ and from Varaždin site $4.16 \mu \mathrm{m}$ (Table 2). Those mean values are in the range of mean values reported by Demi (between $3.36 \mu \mathrm{m}$ and $4.95 \mu \mathrm{m}$ ). Data on fiber lumen diameter are not available in previously mentioned studies and thus could not be compared. Measured fiber characteristics could be classified according to the list of microscopic features for hardwood identification, published by IAWA (Wheeler et al. 2007). This list is comprised of 163 anatomical features, including fiber length and fiber wall thickness. Fiber length was classified into 3 categories and mean values from both sites fit the first category (fibers $\leq 900 \mu \mathrm{m}$ ). Fiber wall thickness was also defined in 3 ways, by

Table 2 Statistical values of fiber length, double cell wall thickness and fiber lumen diameter of white poplar juvenile wood Tablica 2. Statističke vrijednosti duljine vlakanaca, dvostruke debljine stijenki i promjera lumena vlakanaca juvenilnog drva bijele topole

\begin{tabular}{|c|c|c|c|c|c|}
\hline \begin{tabular}{|l} 
Site \\
Stanište
\end{tabular} & $\begin{array}{c}\begin{array}{c}\text { Number of } \\
\text { trees } \\
\text { Broj stabala }\end{array} \\
\end{array}$ & $\begin{array}{c}\text { Value } \\
\text { Vrijednost }\end{array}$ & $\begin{array}{c}\text { Fiber length } \\
\text { Duljina vlakanaca } \\
\mathrm{mm} \\
\end{array}$ & $\begin{array}{c}\text { Double cell wall thickness } \\
\text { Dvostruka debljina stijenki } \\
\mu \mathrm{m}\end{array}$ & $\begin{array}{c}\text { Fiber lumen diameter } \\
\text { Promjer lumena vlakanaca } \\
\mu \mathrm{m} \\
\end{array}$ \\
\hline \multirow{5}{*}{ Osijek } & \multirow{5}{*}{5} & $N$ & 40 & 30 & $25 *$ \\
\hline & & MIN & 0.45 & 2.20 & 7.68 \\
\hline & & MEAN & 0.87 & 3.72 & 13.38 \\
\hline & & $M A X$ & 1.48 & 6.60 & 19.00 \\
\hline & & STDEV & 0.15 & 0.17 & 1.19 \\
\hline \multirow{5}{*}{ Varaždin } & \multirow{5}{*}{5} & $N$ & 40 & 30 & $25 *$ \\
\hline & & MIN & 0.38 & 1.10 & 7.28 \\
\hline & & MEAN & 0.84 & 4.16 & 13.59 \\
\hline & & $M A X$ & 1.72 & 6.60 & 21.51 \\
\hline & & STDEV & 0.15 & 0.30 & 1.45 \\
\hline
\end{tabular}

Key/Legenda: $N$ - number of specimen / broj uzoraka, MIN - minimum / minimum, MEAN - mean value / aritmeticka sredina, MAX - maximum /maksimum, STDEV - standard deviation / standardna devijacija.

* Number of specimen matches number of recorded images for each measured growth ring in five trees (for each of five images, average value of fiber lumen diameter was calculated). / Broj uzoraka odgovara broju snimljenih fotografija u svakome mjerenom godu svih pet stabala (za svaku od pet fotografija izračunana je prosječna vrijednost promjera lumena vlakanaca ). 
Table 3 Results of repeated measures analysis of variance for fiber characteristics of white poplar juvenile wood from two sites and in direction from pith to bark

Tablica 3. Rezultati analize varijance ponovljenih mjerenja svojstava vlakanaca juvenilnog drva bijele topole s dva staništa i u smjeru od srčike prema kori

\begin{tabular}{|l|c|c|c|c|c|c|}
\hline \multirow{2}{*}{$\begin{array}{l}\text { Source of variation } \\
\text { Izvor varijabilnosti }\end{array}$} & \multicolumn{2}{|c|}{$\begin{array}{c}\text { Fiber length } \\
\text { Duljina vlakanaca } \\
\end{array}$} & \multicolumn{2}{|c|}{$\begin{array}{c}\text { Double cell wall thickness } \\
\text { Dvostruka debljina stijenki } \\
\mu \mathrm{m}\end{array}$} & \multicolumn{2}{c|}{$\begin{array}{c}\text { Fiber lumen diameter } \\
\text { Promjer lumena vlakanaca } \\
\mu \mathrm{m}\end{array}$} \\
\cline { 2 - 7 } & $\boldsymbol{F}$ & $\boldsymbol{p}$ & $\boldsymbol{F}$ & $\boldsymbol{p}$ & $\boldsymbol{F}$ & $\boldsymbol{p}$ \\
\hline Site / stanište & 10.25 & $\mathbf{0 . 0 0 1 4 7 8}$ & 68.69 & $\mathbf{0 . 0 0 0 0 0 0}$ & 0.302 & 0.585218 \\
\hline Annual rings / godovi & 442.02 & $\mathbf{0 . 0 0 0 0 0 0}$ & 11.43 & $\mathbf{0 . 0 0 0 0 0 0}$ & 21.870 & $\mathbf{0 . 0 0 0 0 0 0}$ \\
\hline Annual rings*site / godovi *stanište & 0.90 & 0.462828 & 9.29 & $\mathbf{0 . 0 0 0 0 0 0}$ & 2.852 & $\mathbf{0 . 0 2 5 0 4 7}$ \\
\hline
\end{tabular}

fiber lumina in relation to double wall thickness. Based on that relation, fibers from both sites are very thin walled (fiber lumina was 3 or more times wider than the double wall thickness).

Significant differences in fiber length and double cell wall thickness were detected between sites (Table $3)$. Due to soil type and flooding effect on Varaždin site, Osijek site is considered to be more favorable for poplar growth. In this case, the better site accelerated the growth rate and produced trees with longer fibers in the first ten years that were analyzed. This is in agreement with Kennedy and Smith (1959), who found greater fiber length in poplar wood from good sites. According to Peszlen (1994) and Pliura et al. (2007), those differences are most likely related to site edaphic and climatic conditions. This may be explained by several factors. The mean length of the fusiform cambial initials increases gradually as the tree matures. Considerable fluctuation in their length may occur at any time as a result of fluctuating environmental conditions that govern seasonal growth (Panshin and de Zeeuw, 1980). However, fast growth of hardwoods does not always result in meaningfully shorter fibers if wood of equal age is compared (Zobel, 1989). The results did not sup-

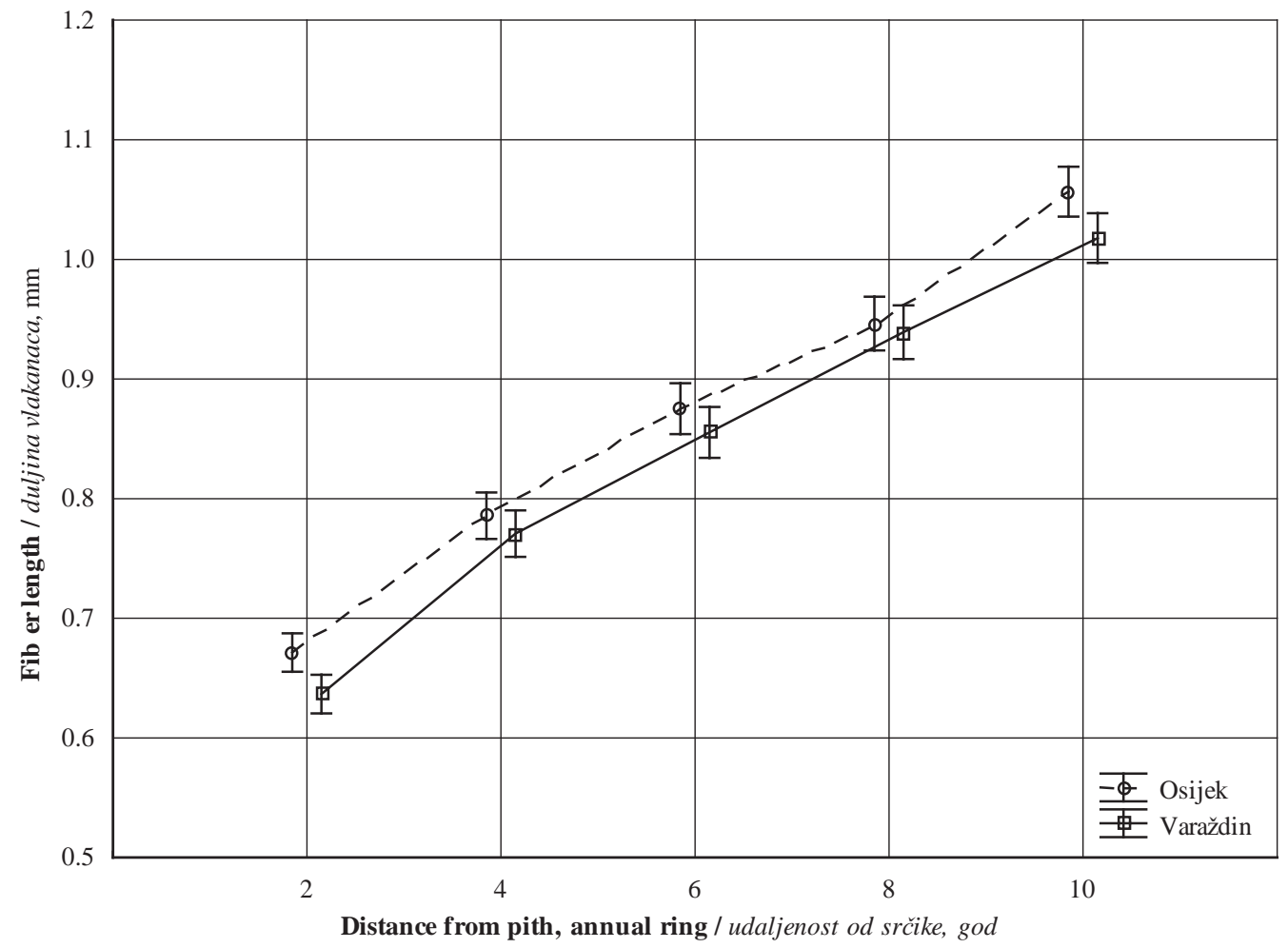

Figure 1 Radial distribution of fiber length of white poplar juvenile wood from two sites

Slika 1. Raspored duljine vlakanaca juvenilnog drva bijele topole s dva staništa u radijalnom smjeru

Table 4 Results of repeated measures analysis of variance for fiber characteristics of white poplar juvenile wood within population from each site

Tablica 4. Rezultati analize varijanci ponovljenih mjerenja svojstava vlakanaca juvenilnog drva bijele topole sa svakog staništa unutar iste populacije

\begin{tabular}{|l|c|c|c|c|c|c|c|}
\hline $\begin{array}{l}\text { Source of } \\
\text { variation / } \\
\text { Izvor } \\
\text { varijabilnosti }\end{array}$ & $\begin{array}{c}\text { Site } \\
\text { Stanište }\end{array}$ & \multicolumn{2}{|c|}{$\begin{array}{c}\text { Fiber length } \\
\text { Duljina vlakanaca } \\
\mathrm{mm}\end{array}$} & \multicolumn{2}{c|}{$\begin{array}{c}\text { Double cell wall thickness } \\
\text { Dvostruka debljina stijenki } \\
\mu \mathrm{m}\end{array}$} & \multicolumn{2}{c|}{$\begin{array}{c}\text { Fiber lumen diameter } \\
\text { Promjer lumena vlakanaca } \\
\mu \mathrm{m}\end{array}$} \\
\cline { 3 - 8 } & & $\boldsymbol{F}$ & $\boldsymbol{p}$ & $\boldsymbol{F}$ & $\boldsymbol{p}$ & $\boldsymbol{F}$ & $\boldsymbol{p}$ \\
\hline \multirow{2}{*}{ Trees / stabla } & Osijek & 29.95 & $\mathbf{0 . 0 0 0 0 0 0}$ & 18.86 & $\mathbf{0 . 0 0 0 0 0 0}$ & 5.34 & $\mathbf{0 . 0 0 4 3 0 2}$ \\
\cline { 2 - 8 } & Varaždin & 19.18 & $\mathbf{0 . 0 0 0 0 0 0}$ & 44.40 & $\mathbf{0 . 0 0 0 0 0 0}$ & 56.99 & $\mathbf{0 . 0 0 0 0 0 0}$ \\
\hline
\end{tabular}




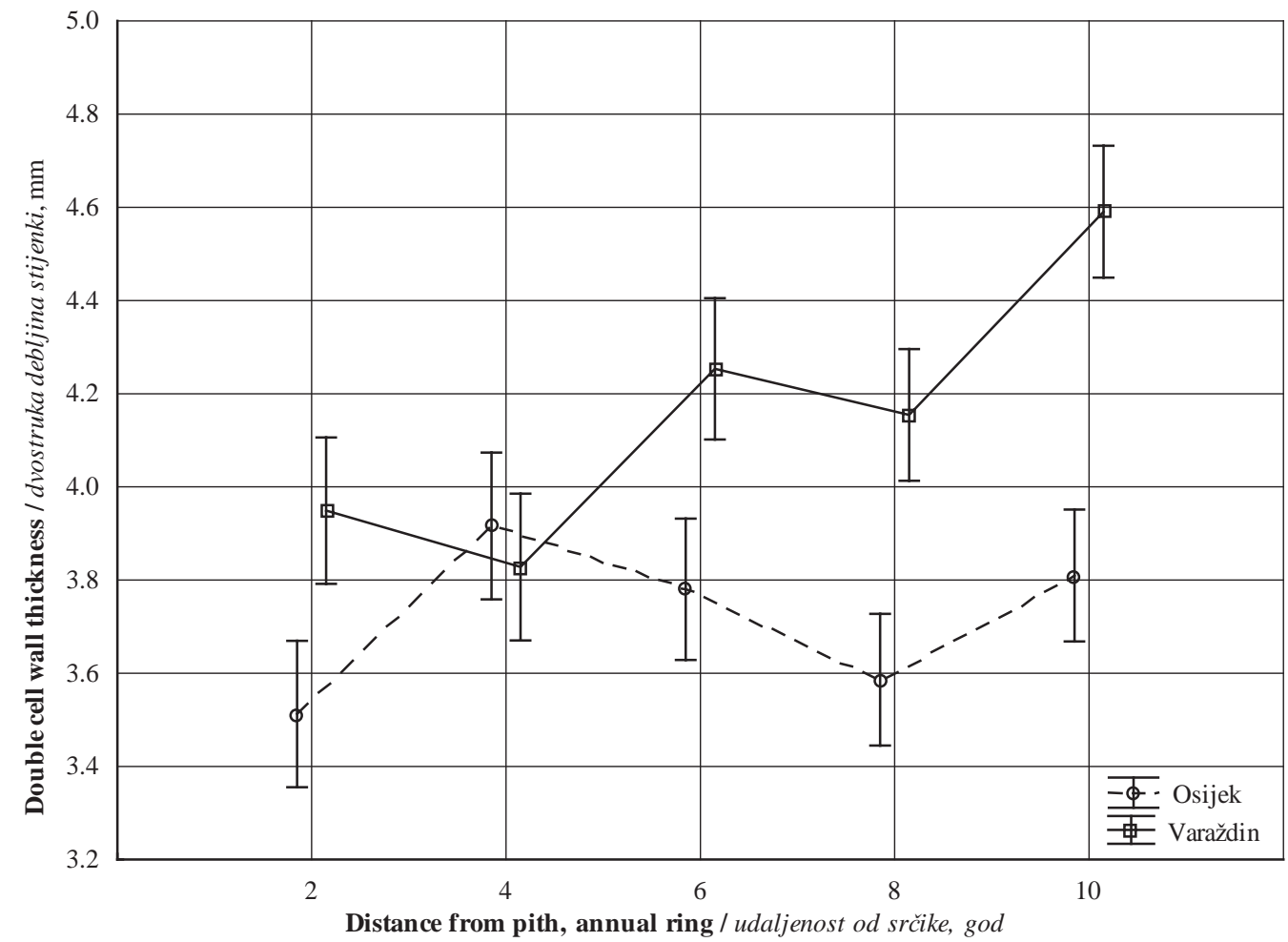

Figure 2 Radial distribution of double cell wall thickness of white poplar juvenile wood from two sites

Slika 2. Raspodjela dvostruke debljine stijenki juvenilnog drva bijele topole s dva staništa u radijalnom smjeru

port earlier findings on poplars and willows (Petrić et al., 1991; Šefc et al., 2009; Zhao et al., 2014). They reported about non-significant difference in selected wood anatomical properties between sites. In this study, difference was non-significant only in fiber lumen diameter (Table 3). According to the results, the change in fiber diameter would be mainly the result of the change in cell wall thickness and not that of fiber lumen diameter.

As expected, fiber length significantly increased linearly from pith to bark in white poplar juvenile wood from both sites (Figure 1 and Table 3). This suggests that cambial age has an important effect on the length of wood fibers. Longer fibers were measured in

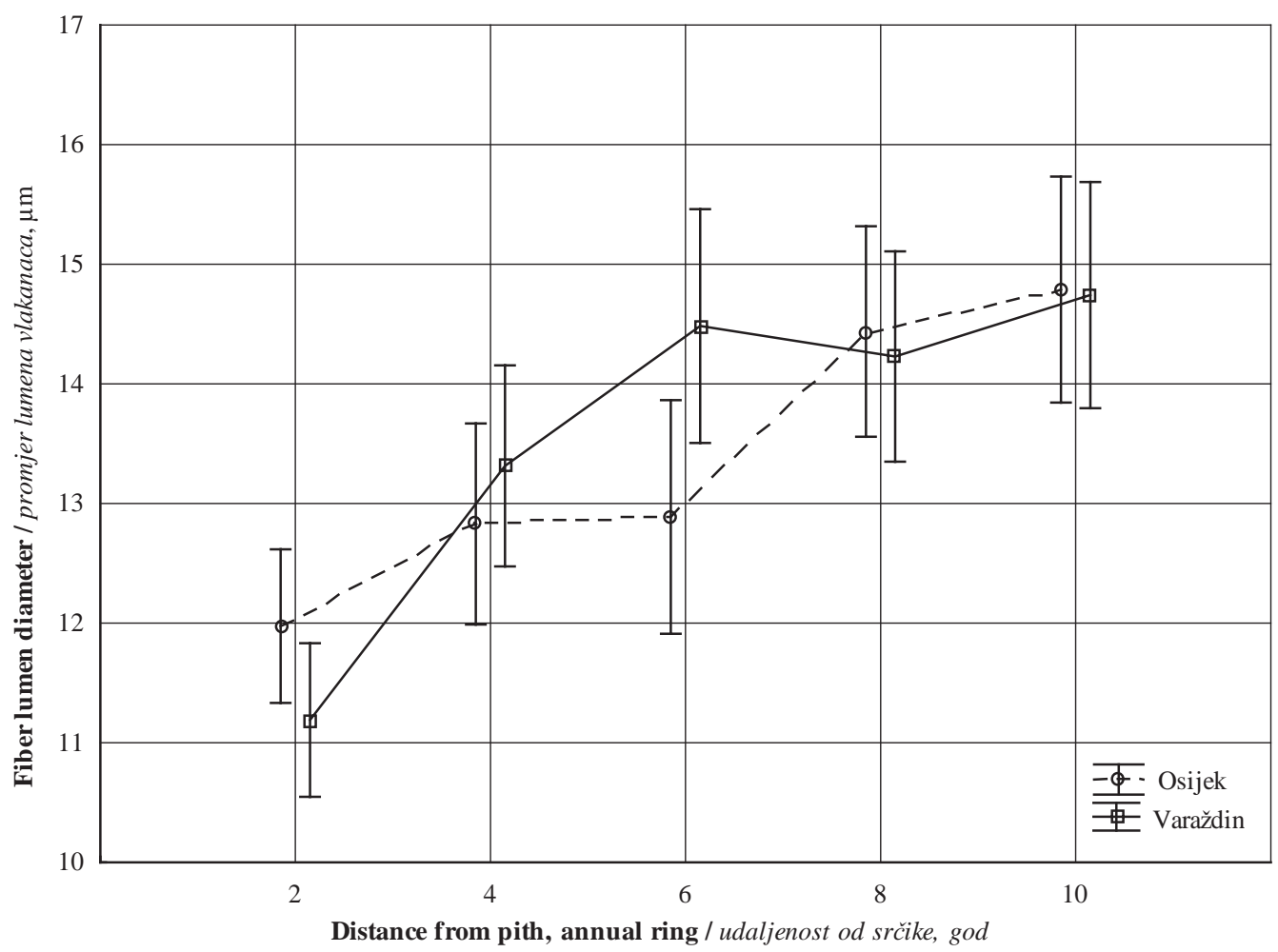

Figure 3 Radial distribution of fiber lumen diameter of white poplar juvenile wood from two sites

Slika 3. Raspodjela promjera lumena vlakanaca juvenilnog drva bijele topole s dva staništa u radijalnom smjeru 
all five annual rings from Osijek site (Figure 1). Significant variation in fiber length from pith to bark of poplar wood was reported by many authors over the years (DeBell et al., 1998; Koubaa et al., 1998; Huda et al., 2012). Double cell wall thickness also varied significantly from pith to bark, with more pronounced change between annual rings in white poplar juvenile wood from Varaždin site (Figure 2 and Table 3). Results from Varaždin site are only partially in agreement with Peszlen (1994) and Huda et al. (2012). Both reported about continuous increase in cell wall thickness with age. Furthermore, fiber lumen diameter showed similar pattern of radial distribution in white poplar juvenile wood from both sites (Figure 3). However, differences in fiber lumen diameter were most pronounced in growth ring 6 from the pith.

There was highly significant difference in fiber length, double cell wall thickness and fiber lumen diameter among trees within both white poplar populations (Table 4). Significant tree-to-tree variation in fiber length of poplar clones was reported by Klašnja et al. (2003), and additionally in fiber lumen diameter and fiber lumen area by Peszlen (1994). This may be explained by response of each tree to differences in its microenvironment, or may be due to large within-tree variation (Zobel and van Buijtenen, 1989; Tsoumis, 1991). Subsequently, variations in a certain site are considered to be higher than between sites. More precisely, variations in wood properties are generally more pronounced within the tree in comparison to variations between trees of one population or between populations (Larson, 1967; Tsoumis, 1991).

\section{CONCLUSIONS}

\section{ZAKLJUČCI}

As expected, the measured juvenile wood fiber characteristics were determined to be highly variable. Fiber characteristics of white poplar juvenile wood from two sites differed. Significant site effect was detected for fiber length and double cell wall thickness. Trees within both white poplar populations had highly significant effect on fiber length, double cell wall thickness and fiber lumen diameter.

There was a general trend in radial direction in both white poplar populations, in which fiber length increased from pith to bark. Double cell wall thickness and fiber lumen diameter also varied significantly with age, but no consistent radial pattern was observed.

For the present study, variations in each site (both within and among trees) were generally more significant in comparison to variations between sites.

Forest product manufacture tends for wood uniformity. Due to highly significant variability, nonhomogeneous wood fiber characteristics were determined within both white poplar populations. In conclusion, variation in wood characteristics provides the possibility to select the breeding stock with desirable wood quality.

\section{REFERENCES}

\section{LITERATURA}

1. Ball, J.; Carle, J.; Del Lungo, A., 2005: Contribution of poplars and willows to sustainable forestry and rural development. Unasylva 221, 56: 3-9.

2. Clark, J. d'A., 1985: Pulp Technology and Treatment for Paper. Miller Freeman Publications, Inc., San Francisco.

3. Dadswell, H. E., 1958: Wood structure variations occuring during tree growth and their influence on properties. J. Inst. Wood Sci., 1: 11-23. In: Bendtsen, B. A., 1978: Properties of wood from improved and intensively managed trees. Forest Products Journal, 28 (10): 61-72.

4. DeBell, J. D.; Gartner, B. L.; DeBell, D. S., 1998: Fiber length in young hybrid populus stems grown at extremely different rates. Canadian Journal of Forest Research, 28 (4): 603-608. https://doi.org/10.1139/x98-031.

5. Dickmann, D. I.; Kuzovkina, J., 2014: Poplars and Willows of the World, With Emphasis on Silviculturally Important Species. In: Poplars and willows: trees for society and the environment, Isebrands, J. G., Richardson, J. (eds.), CAB International and FAO: 8-91.

6. Eggens, C. F.; Longheed, E. C.; Hilton, R. J., 1972: Rooting of hardwood cuttings of boleana poplar. Can J Plant Sci, 52: 599-604. In: Kovačević, B.; Orlović, S.; Kebert, M.; Miladinović, D.; Katanić, M.; Kovinčić, J., 2013: Lead Tolerance and Accumulation in White Poplar Cultivated In Vitro. SEEFOR ISSN 1847-6481: 3-12. https://doi.org/10.15177/seefor.13-01.

7. Franklin, G. L., 1945: Preparation of thin-wood sections of synthetic resins and wood-resin composites, and a new macerating method for wood. Nature, 155: 51. https://doi.org/10.1038/155051a0.

8. Franjić, J.; Škvorc, Ž., 2010: Šumsko drveće i grmlje Hrvatske. Sveučilišni udžbenik. Šumarski fakultet Sveučilišta u Zagrebu, 264.

9. Gilman, E. F.; Watson, D. G., 1994: Populus alba - White Poplar. Fact Sheet ST-499. Environmental Horticulture Department, Florida Cooperative Extension Service, Institute of Food and Agricultural Services, Florida, USA.

10. Horvat, I., 1960: Prilog poznavanju nekih fizičkih i mehaničkih svojstava bijele i crne topolovine (Populus alba L., Populus nigra L.). Šumarski list, 3-4: 95-115.

11. Huda, A.; Koubaa, A.; Cloutier, A.; Hernández, R. E.; Périnet, P., 2012: Anatomical properties of selected hybrid poplar clones grown in Souther Quebec. BioResources, 7 (3): 3779-3799.

12. Isebrands, J. G.; Richardson, J., 2014: Poplars and willows: trees for society and the environment. Published by CAB International and FAO. https://doi.org/10.1079/9781780641089.0000.

13. Kajba, D.; Ballian, D., 2007: Šumarska genetika. Sveučilišni udžbenik. Šumarski fakultet Sveučilišta u Zagrebu i Šumarski fakultet Univerziteta u Sarajevu.

14. Kennedy, R.W.; Smith, J. H., 1959: The effects of some genetic and environmental factors on wood quality in poplar. Pulp Pap Mag Can 60: T35 - T36. In: Zobel, B. J.; van Buijetenen, J. P., 1989: Wood variation. Its causes and control. Springer-Verlag, Berlin, Heildeberg.

15. Klašnja, B.; Kopitović, S.; Orlović, S., 2003: Variability of some wood properties of eastern cottonwood (Populus deltoides Bartr.) clones. Wood Science and Technology, 37: 331-337. https://doi.org/10.1007/s00226-003-0179-3.

16. Koubaa, A.; Hernández, R. E.; Beaudoin, M.; Poliquin, J., 1998: Interclonal, intraclonal, and within-tree variation in fiber length of poplar hybrid clones. Wood and Fiber Science, 30 (1): 40-47. 
17. Larson, P. R., 1967: Silvicultural control of the characteristics of wood used for furnish. Proceedihngs of $4^{\text {th }}$ TAPPI For Biol Conf, New York, 143-150. In: Zobel, B. J.; van Buijetenen, J. P., 1989: Wood variation. Its causes and control. Springer-Verlag, Berlin, Heildeberg.

18. Logan, J. D., 2006: Sensitivity to Fundamental Wood Properties in the Metriguard Model 7200 HCLT and the CLT. Metriguard INC, Pullman, WA. (Source: http:// www.metriguard.com/fiber.php, Accessed Mar. 6, 2017).

19. Maeglin, R., 1987: Juvenile wood, tension wood, and growth stress effects on processing hardwoods. In: Applying the latest research to hardwood problems. Proceedings of the $15^{\text {th }}$ annual hardwood symposium of the Hardwood Research Council; Memphis, TN: 100-108.

20. Peszlen, I., 1994: Influence of age on selected anatomical properties of populus clones. IAWA Journal, 15 (3): 311321. https://doi.org/10.1163/22941932-90000613.

21. Petrić, B.; Trajković, J.; Despot, R.; Krstinić, A., 1991: Varijacije dužine vlakanaca drva breze (Betula pendula, Roth.) iz prirodne populacije na području Hrvatske. Šumarski list, CXV: 273-283.

22. Pliura, A.; Zhang, S. Y.; Mackay, J.; Bousquet, J., 2007: Genotypic variation in wood density and growth traits of poplar hybrids at four clonal trails. Forest Ecology Management, 238 (1-3): 92-106. In: Huda, A.; Koubaa, A.; Cloutier, A.; Hernández, R. E.; Périnet, P., 2012: Anatomical properties of selected hybrid poplar clones grown in Souther Quebec. BioResources, 7 (3): 3779-3799.

23. Šefc, B.; Trajković, J.; Govorčin, S.; Despot, R.; Hasan, M., 2009: Selected tree characteristics and wood properties of two poplar clones. Wood Research, 54 (1): 1-8.

24. Tsoumis, G., 1991: Science and technology of wood: structure, properties, utilization. Chapman \& Hall, New York: 66-83.
25. Wheeler, E. A.; Baas, P.; Gasson, P. E. (eds.), 2007: IAWA List of Microscopic Features for Hardwood Identification. IAWA Bulletin, 10 (3): 219-332.

26. Zhao, R.; Yao, C.; Cheng, X.; Lu, J.; Fei, B.; Wang, Y., 2014: Anatomical, chemical and mechanical porperties of fast-growing Populus x euramericana cv. '74/76'. IAWA Journal, 35 (2): 158-169. https://doi.org/10.1163/22941932-00000057

27. Zobel, B. J.; van Buijetenen, J. P., 1989: Wood variation. Its causes and control. Springer-Verlag, Berlin, Heildeberg.

28. *** DinoCapture 2.0 2015. AnMO Electronics Corporation. (Source: http://www.dino-lite.eu/index.php/en/support/software, Accessed Nov. 19, 2015).

29. *** FAO 1958: Poplars in forestry and land use. FAO Forestry and Forest Products Studies No. 12, Rome, Italy.

30. *** ImageJ 2014. The National Insitutes of Health, USA. (Source https://imagej.nih.gov/ij/download.html, Accessed Oct. 13, 2014).

\section{Corresponding address:}

Assist. Prof. BOGOSLAV ŠEFC, Ph. D.

\author{
University of Zagreb \\ Faculty of Forestry \\ Svetošimunska 25 \\ HR-10002 Zagreb, CROATIA \\ e-mail: bsefc@sumfak.hr
}

